\title{
Cognitive Bubbles: Towards a Logic of Fundamentalism
}

\section{Burbujas cognitivas: hacia una lógica del fundamentalismo}

\author{
Germán Ulises Bula \\ Universidad de La Salle \\ Colombia \\ gbulalo@unisalle.edu.co \\ https://orcid.org/0000-0002-1296-0610 \\ María Clara Garavito \\ Universidad de La Salle \\ mcgaravitog@unal.edu.co \\ https:/orcid.org/0000-0002-5185-6824 \\ Sebastián Alejandro González Montero \\ Universidad de La Salle \\ sgonzalez@unisalle.edu.co \\ https://orcid.org/0000-0001-6271-0276
}

Recibido: 29 - 05 - 2019.

Aceptado: $04-10$ - 2019.

Publicado en línea: 28 - 10 - 2020. 


\begin{abstract}
This paper examines fundamentalist cognition from a formal perspective with the aim of showing that such a perspective has explanatory power. Formal traits in fundamentalist thought are shown to turn up consistently in different fundamentalist groups and regarding different issues, and to be related to fundamentalist groups' dynamics, theology, and political organization. Analysis of fundamentalist cognition also suggests that the epistemological stance of strong relativism in the public sphere may be conducive to fundamentalism.

Keywords: fundamentalism; epistemology; relativism; rationality; religion.
\end{abstract}

\title{
Resumen
}

Este texto examina la cognición de los fundamentalistas desde una perspectiva formal con el propósito de mostrar que dicha perspectiva tiene poder explicativo. Se muestra que hay rasgos formales consistentes en la cognición de diversos grupos fundamentalistas y en relación con diferentes temáticas, y se muestra que dichos rasgos se relacionan con las dinámicas, la teología y la organización política de los grupos fundamentalistas. Un análisis de la cognición fundamentalista también sugiere que la postura epistemológica del relativismo fuerte en la esfera pública puede conducir al fundamentalismo.

Palabras clave: fundamentalismo; epistemología; relativismo; racionalidad; religión. 
World events in the last two decades have increased attention to phenomena such as authoritarianism, terrorism, religious fundamentalism, and the return of religion to the public sphere (e.g., Aslan, 2010; Bruce, 2008; Fallacci, 2002; Harris, 2005). ${ }^{1}$ These interrelated phenomena have been studied chiefly from a psychological and a sociopolitical point of view (e.g., Altemeyer, 2006; Armstrong, 2009a). This paper is interested in the cognitive properties of the fundamentalist mind; that is, in the way in which ideas interact therein in order to sustain unreasonable beliefs (see Schimmel, 2008). Our focus, then, is on cognitive fundamentalism (CF), which can be ascribed to religious fundamentalists (RFs), but also, for example, to economists who have an unreasonable faith in the self-regulating power of markets (see Boldeman, 2011; Freedman, 2008; Klein 2007), or to climate change denialism in the face of overwhelming scientific evidence (see Dunlap \& McCright, 2011). In short, the aim is to study fundamentalism in as much as it is a "habit of mind" (Mercer, 2013, p. 136).

This paper is programmatic: the aim is to show the viability and fruitfulness of inquiry into the cognitive properties of the fundamentalist mind (this implies showing at least the plausibility that there is such a thing as a fundamentalist mind). To this end, examples of common formal traits in fundamentalist thinking will be furnished, and shown to turn up across different kinds of fundamentalist belief systems. These formal properties of fundamentalist thought will be shown to be related to psychological and sociopolitical traits of fundamentalist groups and individuals, and therefore to show promise of explanatory power. Finally, the formal analysis of fundamentalist thinking will be shown to suggest ways of dealing with CF in the public sphere.

\section{Some Definitions}

Although the focus of the paper is formal, there will be ample reference to sociopolitical and psychological studies of RFs, right wing authoritarians (RWAs) and movement conservatives (MCs). Therefore,

1 This work is a partial result of the project "Metrocosmética: sobre la satisfacción superficial de indicadores y mediciones en el campo de la educación" financed by the Vicerrectoría de Investigación y Transferencia (VRIT) of the Universidad de la Salle of Bogotá, Colombia. 
some definitions are in order. RWAs are people who fit a psychological profile likely to support authoritarian politics: they are submissive to authority, aggressive to outsiders and highly conventional; they tend to think of authority figures as above the law (recall Richard Nixon's famous statement on Watergate: "when the president does it, that means it is not illegal"; see Frost, 2007), and they tend to show higher levels of fear and aggression, which are released by feelings of self-righteousness (Altemeyer, 2006, pp. 9, 18 \& 57). RFs are those who believe that a given set of religious teachings is inerrantly and straightforwardly true and must be followed according to unchangeable laws, that these teachings are opposed by evil and must be fought, and that those who follow them have a privileged relationship with the deity (Altemeyer \& Hunsberger, 2004 , p. 118). Both profiles have been shown to have predictive value; there is evidence of a large overlap between the two categories (Hathcoat \& Barnes, 2010, p. 73); and links have been found between religiosity and traits such as authoritarianism (Duck \& Hunsberger, 1999), stereotypical thinking (Watson et al., 1999), a need for reduction of uncertainty and a concomitant reduced openness to change (Schwartz \& Huismans, 1995), and prejudice (Batson et al., 1993). Finally, movement conservatives are people in the USA who support the ideological movement that emerged in the 1950's and includes such positions as economic libertarianism, Christian theocracy, opposition to the regulation of gun ownership and opposition to minority rights (see Carter, 1999; Edwards, 2010; Lehman, 2015; Nash, 2009); many MCs are RWA (Altemeyer, 2006) and evangelical RFs (Williams, 2010). How CF manifests itself in all three groups will be shown through varied examples.

Methodologically, this paper will eschew what US political blogs have dubbed "nutpicking", that is, selecting examples from fringe groups or individuals in order to paint larger political movements as extremist (a version of the straw man fallacy called "the weak man fallacy"; see Aikin \& Casey, 2010); all examples of CF will therefore come from recognized religious authorities, elected political officials, recognized academics or otherwise authorized voices.

\section{The Origin of Fundamentalism}

From a historical perspective, the phenomenon of religious fundamentalism is broadly seen as essentially modern: in the face of rapid change (such as the advancement of technology, or globalization), certain groups of people devise fundamentalist doctrines and 
practices in order to preserve their identity, which they perceive as threatened; while these doctrines and practices look longingly towards an idealized past, they are not identical to pre-modern ones in that fundamentalism functions not only as a form of religious belief but also as an ideology (Mercer, 2013, p. 136; Armstrong, 2009a). Whereas progress and modernity are seen by many as positive changes, wouldbe fundamentalists experience modernity as a violent intrusion from without; for example, in the Near East the process of modernization is often seen as one of western pillaging, cultural impoverishment and poor imitation of inadequate models (Armstrong, 2009, p. 169).

Karen Armstrong argues that traditional religions understood their teachings as myths that were not so much believed in as factual truths, but rather were used, in combination with religious practice, to deal with human needs such as the search for ultimate meaning or taking heart in times of crisis; in stark contrast, modern religions (and fundamentalist religions most of all) place a central emphasis on giving assent to the propositions that constitute religious dogma (Armstrong, 2009b). In fundamentalism, the mythical narratives of old are taken literally, and become precise practical guides for action instead of broad horizons of meaning: the Jewish longing for the Promised Land which once symbolized a permanent yearning for a just and holy society becomes a precise instruction to occupy a biblically specified portion of the southern Levant; the Islamic "death of the self" once understood as a spiritual exercise is now taken to be an invitation to self-immolation in war against the infidels; the narrative in Genesis is no longer an allegorical way of addressing existential questions such as "why are we here?" and "why must we work?", and becomes an instruction to oppose the theory of evolution (Armstrong, 2009a, pp. 199-201 \& 406; Barbour, 2000; Taverne, 2005).

In this way, religious beliefs turn into ideologies and become ossified, trivialized and Manichean (Armstrong, 2009a, pp. 288-299). When emphasis is put on belief in dogma rather than religious practice, the contents of dogma are seen as central and unchangeable. In order to function as an ideology, these contents must be easily transmittable and understandable by a broad public, and are therefore simplified: for example, broad sectors of US fundamentalist Protestantism reject complicated biblical scholarship in favor of subjective and emotional readings of the Bible, and generally embrace a populist ethos that rejects the rule of scholars and experts (Armstrong, 2009a, pp. 128-129). These 
simplified ideologies tend to embrace a Manichean "us vs them" view of the world: protestant fundamentalists in the US see secular humanism as the all-pervading enemy and, tellingly, as a rival religion (Armstrong, 2009a, p. 341); al-Qutb (an influential Islamic scholar that provided inspiration to Osama Bin Laden) divides the world into jahilliyah (pre-Quranic ignorance) and ummah, the community of the righteous, Islam vs everybody else (Harte, 2013, pp. 159-160), and believed there was a conspiracy against Islam that included zionists, capitalists and communists (Armstrong, 2009a, p. 309). The idea of a conspiracy with so many diverse and antagonistic participants is the kind of unreasonable belief that can be considered a form cognitive fundamentalism. ${ }^{2}$

\section{Cognitive Bubbles}

$\mathrm{CF}$ has a new source in new information technologies. This has been widely discussed with regards to MCs, who tend to become radicalized and isolated from differing opinions because they get their information

2 The topic of conspiracy theories leads to another interesting feature of the fundamentalist mind that can only be alluded to here. Zwierlein \& de Graaf (2013, pp. 13-14) trace the origins of conspiracy theories to the early modern period, because a precondition for conspiracy theory is the existence of a public sphere that provides a consciousness of the present to which conspiracy theories are parasitic. More importantly, the public sphere creates a consciousness of broad systemic forces affecting politics (e.g. the "chessboard of Europe" in early modernity), that is, a consciousness of system inclusion and system instability (Zwierlein \& de Graaf, 2013, p. 14). This "opens up a new emotional space to be filled with fear and worry about the stability of the whole" (Zwierlein \& de Graaf, 2013, p. 15); this fear, rather than attaching to the systemic properties of a whole, attaches to "fearful images of a secret power which in fact controls everything" (Zwierlein \& de Graaf, 2013, p. 15). Thus, in the confessional age, European politics are thought to be controlled by the Antichrist; in the eighteenth century, this is replaced by a conspiratorial force that is opposed to the French Revolution as a sort of shadow of Rousseau's "general will", a faction that is to the general will what the Antichrist is to the true church (Zwierlein \& de Graaf, 2013, pp. 15,20 ). From these ideas, we can hypothesize that this sort of paranoid thinking is either blind to, or intolerant of, emergent properties; that is, of properties of systems that are the product of interactions between the parts rather than of the planning of some conscious agent (see, e.g., Resnick, 2000); as a response, these kinds of minds would tend to attribute these properties to some centralized conscious conspiracy. 
on politics exclusively from conservative sources (this mirrors the trend of RFs, who culturally set themselves apart from the modern world; see Ruthven, 2005, p. 201). Cato Institute writer Julian Sanchez (2010a) called this phenomenon "Epistemic Closure", a name which became common currency among political commentators. Since "epistemic closure" also refers to the idea, in epistemology, that the set of things entailed by the things we know is finite (e.g., Bogdan, 1985), we prefer to use the term "cognitive bubbles", which is less potentially confusing.

New information technologies amplify the user's role in the selection of the media products he is to view. This potentially empowering development (Levy, 1999) can also lead to cognitive bubbles as people with a given ideological slant will select media that reinforces it in a positive feedback loop (Sunstein, 2003). In the case of conservatives, this tendency is reinforced by politically motivated news outlets such as Fox News (Bartlett, 2015), which have formed a "closed media ecosystem" (Sanchez, 2010b) in which the only sources used by conservative outlets are other conservative outlets.

CFs display modulated skepticism: they show a high degree of skepticism towards news that disagree with their worldview, and a low degree of skepticism towards news that agree with it, beyond what can be expected from the normal psychological trait of confirmation bias. As an example, many MCs believed a conspiracy theory that a routine US military exercise called Jade Helm 15, which took place between July and September of 2015, was the beginning of a federal takeover of states hostile to liberalism. This prompted Texas governor Greg Abbott to instruct the state guard to monitor the operation, thereby giving legitimacy to fears that, according to the New York Times, crossed "the outer edges of political paranoia" (Fernandez, 2015).

Analysis on the use of Facebook shows that the tendency of users to seek out only information outlets which reinforce a pre-accepted narrative helps spread and strengthen such conspiracy theories (Del Vicario et al., 2015). MCs who believed the Jade Helm conspiracy theory gave more credence to obscure websites and anonymous Facebook posts than to official government sources and respected news outlets.

This can be explained by the isolationist group dynamics of fundamentalists. Sociologist Georg Simmel posits that multiple group affiliations strengthen a person's individuality: groups determine a person's traits, but a person that belongs to multiple groups can carve 
out an individual identity in the tension produced by the conflicting demands of the different groups he belongs to; conversely:

[A] group which wants its members to become absorbed unconditionally in its activities must regard it as incompatible with this principle if an individual is differentiated from other members by virtue of his simultaneous affiliation with another group (1955, p. 146). ${ }^{3}$

This seems to be the case with fundamentalists: the radical Zionist group Gush Emunim defines itself against mainstream Israeli society, and has created a whole counterculture that includes a particular style of dress, music, and speech (Armstrong, 2009a, p. 351); Christian fundamentalists use the slogan "Be ye separate!" and have an extensive network of institutions that promote a life apart from "worldly ways" (Mercer, 2013, pp. 144-145). The claim to exclusive affiliation includes information sources: news must only be heard from members of the tribe; other news come from hostile outsiders and must be viewed with suspicion.

Why are CF's prone to forming cognitive bubbles? According to Sarouglou (2002), RFs exhibit a high need for closure, that is, a marked preference for order in their lives, discomfort with ambiguity, preference for predictability and stable knowledge, close-mindedness defined as a desire not to be confronted by alternative opinions or beliefs, and decisiveness defined as a need for closure in judgment and decision making (Saroglou, 2002, p. 186). This need for closure could explain the aversion or RF's to ideas that challenge their own: they would not be adverse to "otherness" as such, but rather to the cognitive and practical disorder that otherness introduces (Saroglou, 2002, p. 185). Perhaps this is a general trait of $\mathrm{CFs}$, a preference for totalizing explanations based on a few simple principles that make for an orderly world-what Popper (1962, pp. 33-58) characterized as the "dogmatic attitude".

\section{Epistemology}

A closed media ecosystem is only a partial explanation of CF. Let's look at their personal epistemology, that is, the beliefs about knowledge

3 See also Maalouf (2012) for a similar argument. 
held by fundamentalists. Both RFs and RWAs believe knowledge to be simple, certain, and derived from omniscient authority (Hathcoat \& Barnes, 2010, p. 74). Research suggests that this epistemology, which is implicit in RF teachings (that transmit a simplified and dogma-centered version of religion), may be part of the reason that so many RFs are also RWAs: indeed, such an epistemology would account for submissive attitudes to authority, conventionalism, and hostility to outsiders who perversely refuse to accept "plain-as-day" religious truths (Hathcoat \& Barnes, 2010, p. 76).

A possible corollary of this epistemology is a tendency to neglect testing the contents of dogma (Saletan, 2010). A prominent belief among MCs is that, historically, there has been very little mistreatment of minorities in the USA, and that their inferior social status is rather the product of their own failings (e.g., the Irish are alcoholics, AfricanAmericans are bad parents, etc.); this belief is reflected in prominent conservative scholar Richard Jensen's (2002) contention that "No Irish Need Apply" (NINA) disclaimers in job postings in the early nineteenth century were rare or non-existent, and rather a myth promoted by antiprotestant Irish. In 2015, then 14-year-old Rebecca Fried refuted Jensen's claims by using the search engine Google, and finding, for example, that the New York Sun newspaper ran 15 NINA ads in one year alone (see Thompson, 2015). Such a development reveals a telling negligence in Jensen's efforts at testing his own claims.

If truth is a set of divinely authorized atomic propositions rather than a connected network, then implied contradictions between propositions are unimportant (Hathcoat \& Barnes, 2010, p. 75). RWAs may state, for example, that the USA stands for peace and international cooperation and also that it should be able to attack whoever it wants without asking permission, never noticing the tension between both statements (Altemeyer, 2006, p. 98); in general, the fundamentalist mind can be characterized as a filing cabinet with compartmentalized and unrelated beliefs (Altemeyer, 2006, p. 75), wherein a proposition $\mathrm{P}$ will be held to be true, but not all the propositions that $\mathrm{P}$ logically entails. Prominent conservative columnist Ross Douthat attributes this compartmentalization to the conservative movement as a whole:

[...] pro-lifers handle abortion, Grover Norquist handles taxes, the neoconservatives handle foreign policy and the Competitive Enterprise Institute handles 
environmental regulations and nobody stops to consider if the whole constellation of policy ideas still makes sense [...] (Douthat, 2010).

\section{Contradictions}

What is the unifying force behind the conservative movement's various factions? According to many commentators, it is simply the opposition to liberal policies (Saletan, 2010). If MCs define themselves chiefly by opposition to liberalism, then the set of their beliefs contains a significant number of propositions that are generated by negating "liberal" propositions. Logically, the "mirror image" of a coherent set of interrelated propositions (that is, that same set with a negation preceding all propositions) will be incoherent, because valid entailments for a given set of propositions may not be valid for their negation (for example, "Fido is a mammal" is a valid entailment of "Fido is a dog"; but "Fido is not a mammal" is not a valid entailment of "Fido is not a dog"). Independently of whether liberalism is roughly coherent or not, one would expect MC beliefs to be mostly incoherent. Antagonistic thinking (a tendency to think the opposite of whatever a given actor thinks $)^{4}$ leads us to expect contradiction and compartmentalization.

How do CFs deal with contradictions? An interesting trait in their thinking has been called "swallowing the toad" (Bula, 2014, p. 25): when faced with a reductio ad absurdum argument, in which a proposition (P) is refuted by deriving an absurd conclusion from it (Q), CFs will accept Q as true rather than revise P. In 2006, liberal blogger Mike Stark put forth the following argument to anti-abortion conservatives who hold that life worthy of protection begins at conception: "Imagine that you're in a burning fertility clinic with a 2-year-old baby and a petri dish containing five blastulas. You can't save both, so which do you save?"

4 The term antagonistic thinking could be taken in a broader, psychological sense that goes beyond the narrow, formal scope of this paper; it is however, worth mentioning it, as the two meanings could be related. Schneider states that the fundamentalist "can, in a certain sense, be psychologically typed as a paranoiac"(2002, p. 20), in that he projects his inner struggles and anxieties to the outside world, and, in his fear of the other, sees the other as a mere thing (Schneider, 2002, pp. 21-23). In a general sense, the paranoid personality sees itself pitted against the world in an adversarial fashion; for example, blaming others, or his environment, for his personal failures (see Bonner, 1950). 
(Grieve, 2006). Pennsylvania Senator Rick Santorum answered that he would "try to rescue as many of those children as possible" (Edwards \& Webster, 2011), which means that Santorum would actually expend efforts to save a petri dish in a burning building containing a two year old in peril.

Pro-gun organizations such as the NRA oppose gun control by holding that safety is increased when more people are holding guns, because, according to them, the antidote to a "bad guy with a gun" is a "good guy with a gun". Surely this can be shown not to hold universally: what about places with minors, or with mentally unstable people? Well, conservative states are promoting the carrying of guns in schools and universities, the arming of teachers and janitors, and even, in Texas, to allow carrying guns in mental health institutions (Zimet, 2015; Jervis, 2016). This absurd conclusion is not used to question the premise that more guns are always better but is rather used earnestly as a basis for public policy.

Swallowing the toad is not to be taken as a synonym of biting the bullet (e.g., Warburton, 2000, pp. 28-29). Whereas biting the bullet means accepting an unpleasant or tough to defend corollary of a philosophical position, in order to preserve the coherence of one's beliefs, swallowing the toad means accepting an absurd conclusion, not with a view towards preserving a coherence in beliefs, but rather in an ad hoc manner, as a way to preserve a cherished belief in the context of a particular discussion.

\section{Pseudocognitive Acrobatics}

Swallowing the toad is one of many "pseudocognitive acrobatics" (Schimmel, 2008, p. 29) that CFs use to preserve cherished beliefs. RFs actively seek out information that confirms their existing beliefs and try to explain away information that is detrimental to them (Hill et al., 2010, p. 726). Indeed, RF thinking is characterized by a particular relationship between central and peripheral beliefs: when peripheral beliefs put central beliefs into question, the peripheral beliefs are systematically modified or discarded (Saroglou, 2002, p. 184; see also Popper, 1962, p. 49 for a similar characterization of the dogmatic attitude).

Pseudocognitive acrobatics show that CFs have the capacity for critical thinking, but it is only marshalled against ideas that contradict their beliefs (Altemeyer, 2006, p. 78). Fundamentalist pseudocognitive acrobatics are not forms of lazy or sloppy thinking; there is no lack of effort 
in these endeavors. Rather, there is a cognitive effort expended in the preservation of certain cherished ideas. A good example is the creationist Answers in Genesis institute, which offers detailed explanations on how Noah could fit all the animals in the Ark (he took cub specimens, and he did not take every species of animal but rather every "kind", which is a broader category), how the animals were cared for (Noah, being over 500 years of age, would have the knowledge to implement an automatic feeding and watering system), what the dinosaurs in the Ark ate (dried meat for the carnivores), etc. (Woodmorappe, 2013).

It is hard not to find some of these acrobatics risible (though it is worth keeping in mind that the extremist NRA agenda is a reality in many US states, and that Answers in Genesis is no small organization: it has built a creationist theme park in Northern Kentucky costing hundreds of millions of dollars), but the interest here is not in the contents of these ideas but in their form. The question is about the workings of the fundamentalist ecology of mind (the set of interacting ideas in a given mind; see Bateson, 1987, p. 1). An apt intuitive image is that of a machine with rigid and moving parts, where the non-rigid parts strive to move around so that the rigid parts can remain fixed.

Whereas empirically grounded or logically demonstrated beliefs (e.g., that my workplace is two blocks from the bus stop, or that the sum of the interior angles of a triangle is $180^{\circ}$ ) need no reinforcement but are easily incorporated into an individual's ecology of mind once experienced or understood, the beliefs of fundamentalists seem to need to be propped up; all the more so, the more a belief clashes with reason or experience. To believe that $1+1=2$ requires a one-time exercise; the belief that the earth is 6000 years old requires weekly booster shots and a religious choir. There is a characteristic "adhoc-ness" to fundamentalist thought; the cognitive bubble is not a mere consequence of belonging to a certain group or watching a certain news channel, but rather the result of pseudocognitive work that defends certain ideas. Perhaps this adhocness can be used as a measure of the empirical and logical groundedness of a worldview, roughly in the way that an excess of local fixes (e.g., epicycles in the Ptolemaic system of astronomy) can signal a deficient scientific paradigm (Kuhn, 2012).

As a formal failing, adhoc-ness is short of contradiction, and is indeed a way to address emerging contradictions. Traits such as the compartmentalization of ideas, antagonistic thinking, and the technique of swallowing the toad to deal with reductio ad absurdum arguments lead 
one to expect a great deal of contradictions in fundamentalist thought. Altemeyer's research has shown the presence of double standards and arguments based on contradictory principles in RWA thought: for example, when asked whether US public schools should teach Christianity, they will answer in the affirmative, citing the rule of the majority; but when asked whether public schools in an Arab country should teach Islam, they cite minority rights (Altemeyer, 2006, pp. 116117). What can be expected of a form of thinking that systematically produces contradictions?

\section{The Principle of Explosion}

While some degree of contradiction is to be expected of any human belief system, the systematic production of contradictions seems to be a defining characteristic of fundamentalist thought. Therefore, the question of whether something like the principle of explosion applies to $\mathrm{CF}$ is warranted. In classical logic, if a proposition and its negation are accepted in a theory, then any theorem can be derived, rendering the theory trivial. For example, if a theory accepts both "all cars are blue" $(\mathrm{P})$ and "all cars are not blue" $(\neg P)$, then we can affirm $P$ and weaken it to "all cars are blue or traffic jams are pleasant" ( $\mathrm{P} \vee \mathrm{Q}$, where $\mathrm{Q}$ is arbitrary). Then, through conjunctive elimination (because $\neg \mathrm{P}$ is taken as true), we can derive that traffic jams are pleasant. Paraconsistent logical systems can avoid the principle of explosion by keeping contradictions localized; but fundamentalist thought produces contradiction systematically, not in a localized manner.

The principle of explosion points at the broader fact that, without some form of the principle of non-contradiction, there is no criteria to distinguish truth from falsehood (or better and worse beliefs), so "anything goes". Throughout history, extremist religious movements have displayed a characteristic form of irrationalism that calls to mind the phrase "anything goes": after the Jewish kabbalist Sabbatai Zevi proclaimed to be the Messiah in 1648, he and his followers started violating Jewish religious law as a form of "holy sin", and believers alternatively mortified themselves and danced in the streets in fits of ecstasy (Armstrong, 2009a, pp. 59-62). In 1666 Zevi was captured by the Ottoman authorities that feared a revolt, and was given the choice between death and conversion to Islam; when Zevi converted, some of the Sabbateans remained faithful, and developed a doctrine of an Apostate Messiah (Armstrong, 2009a, pp. 62-63), an example of pseudocognitive 
acrobatics if there ever was one. The Great Awakenings of the 18th century, in which American colonists turned massively to evangelical forms of religion, saw alternating fits of ecstasy and depression, religious suicide, and a marked turn from traditional religion (guided by tradition, ritual and doctrine), towards a spontaneous and emotional form of religiosity, that believers experienced as a form of freedom (Armstrong, 2009a, pp. 119-120).

Both in North America and in countries like India, the televised nature of religious evangelizing (with such odd features as the recurring and customary performance of miracles, e.g. in the $700 \mathrm{club}$ ) has given it an air of irreality that borders on the self-parodic (Ruthven, 2005, pp. 205- 207). The ministry of televangelists Jim and Faye Bakker, beginning in the late 1960s, marked a sharp turn in 20th century American fundamentalism, from a sober tone and a rigid attention to dogma to a bombastic, emotional and subjective approach to religiosity that fused it with Disney-style entertainment (Armstrong, 2009a, pp. 437-438). Their preaching insisted on God's infinite indulgence for believers, so strongly that it seemed to promote sin (this sort of theological bent is known as antinomianism); perhaps fittingly, their popularity fell sharply during the 80 s after revelations of the couple's extravagant lifestyle, sexual scandals (including rape) and criminal charges for fraud (Armstrong, 2009a, p. 438). Televangelist Jimmy Swaggart benefitted from the Bakker's downfall, and popularized an even more emotional and irrational form of religiosity (that included speaking in meaningless tongues), until his own downfall in 1988 due to a prostitution scandal (Armstrong, 2009a, p. 439).

There is more to this pattern of extreme religiosity and nasty scandals than mere hypocrisy. Both the Bakkers and Swaggart embraced a doctrine of divine indulgence, which has been dubbed "cheap grace" (see Bonhoeffer, 1979): once you have been saved by faith, you have free reign to behave as immorally as you want (Altemeyer, 2006, p. 133). From the point of view of the believer, this infinite indulgence is experienced as freedom from both moral constraints and from critical thinking (see Wright, 1993, pp. 81-82): in cheap grace, Christ's sacrifice is taken to give the believer full freedom without need for discipleship or even contrition; on the contrary, the acceptance of costly grace implies the rejection of a self-willed life (Bonhoeffer, 1979, pp. 47-54). Perhaps 
this idea of freedom as "anything goes" (both morally and cognitively) ${ }^{5}$ is the manifestation of the principle of explosion in CF.

Of course, many religious fundamentalists accuse secularists of being on the side of "anything goes", for example, in relation to sexuality (e.g., O'Clock, 2015), and consider themselves to be on the side of moral absolutes as opposed to moral relativism. There is a distinction to be made: this opposition to relativism is a content of many fundamentalist stances, whereas the erosion of criteria in deciding between competing claims is a formal trait of fundamentalist thinking, apart from its contents. Witness, for example, the "return of the religious" in North America, spearheaded by the Christian Right: in order to gain political power, and while proclaiming absolute values, the protestant Old Guard has allied itself in a common front with Mormons, Catholics and Jews (that is, with Idolaters, Popists and Christ-deniers, if their absolute values held true); so fundamentalists themselves are, in practice, ironically tolerant (Ruthven, 2005, p. 204).

In Marvin Minsky's (2010) model of the mind, there are mental resources that produce new ideas and critical resources that suppress unfit ideas. Minsky posits that the cognitive process can be described as bipolar, with micromaniacal phases in which new ideas are generated, and microdepressive faces in which ideas are critically culled (Minsky, 2010, p. 308). From this point of view, the emotional, irrational and antinomianist religiosity of the likes of Jimmy Swaggart can be seen as a maniacal kind of thinking, in which critical resources have been shut down.

\section{Popping Bubbles}

The problem with institutions like Answers in Genesis or people like Rick Santorum is that they are influential; CF undermines the rationality

5 Perhaps politically as well: "Extremism in defense of liberty is no vice. Moderation in pursuit of justice is no virtue"; these words, spoken by Barry Goldwater in his 1964 republican convention acceptance speech, give a glimpse into the mind of RWAs, which are guided by narratives of fear and loss (Oakeshott, 1961, pp. 168-196). Peace, civility, reasonableness may be eschewed in the pursuit of a world that fits their ideology (Sorel, 1925, pp. 205-206; Ruthven, 2005, pp. 1-33; Robin, 2011); in order to save the world from its current moral ruin and to retrieve an idyllic past (Payne, 2003, pp. 94-101; Robin, 2011, p. 73), anything goes. 
of the public sphere. It is possible that certain epistemological positions held inside and outside academia contribute to this erosion of rationality. This may be the case of strong relativism, "the view that no belief, [...] practice, or assumption of a given sort is worthier of adherence than any other" (Goodman, 2001, p. 90). In what follows, critical remarks will be made specifically about strong relativism, and must not be understood to apply to, for example, epistemological pluralism (see Goodman, 2001, pp. 89-95). That strong relativism can be related to CF is suggested by a common formal property: the absence of a criterion to distinguish truth from falsehood, or good ideas from bad ideas. This was suggested to be a property of $\mathrm{CF}$ through the principle of explosion, and it is the defining trait of strong relativism.

The epistemological case against strong relativism is solid and well known: even if it is accepted that all observations are theorydependent or paradigm-dependent, even if paradigms are mutually incommensurable, there exist independent criteria for choosing one theory or paradigm, such as the stability, comprehensiveness, elegance, or internal coherence of a theory (Goodman, 2001, pp. 96-102). The allure of relativism does not lie in the soundness of its epistemology, but is, rather, political (Goodman, 2001, pp. 89-95): relativists see themselves as open minded, respectful of the point of view of others, and as rejecting such things as western epistemological colonialism and logocentrism (see e.g., Aragón \& Ranulfo, 2013; Grosfoguel, 2011). It would seem that embracing relativism could help lead to a more open, peaceful and tolerant society.

Is this actually the case? Relativism, by accepting all beliefs as equally valid, rejects any epistemological criteria for preferring one over the other; so, in the case of a dispute, there is nothing left but Realpolitik (Goodman, 2001, p. 89). The relativist has no theoretical weapons with which to criticize the fundamentalist; in fact, he is in the same boat: he has affirmed that anything goes. If he is to be consistent, the relativist will see fundamentalist thought as valid for a given community. He must face the paradox of tolerating intolerance, and its very real political consequences (see Guiora, 2014). As for the fundamentalist, he is put in an ambiguous relationship to relativism: on the one hand, he is validated by relativism (as holding one more perspective that must be granted validity); but on the other, it does not grant the fundamentalist the right to silence other positions (Ruthven, 2005, pp. 197-198). 
In as much as relativism operates in the public sphere, it encourages habits of mind that overlap with those of fundamentalism: anything goes. We believe that the emergence of CF is facilitated by the transmission of these habits of mind in the public sphere. In the name of journalistic objectivity, news media outlets have adopted such a relativistic attitude, flatly covering both sides of a controversy on equal footing (e.g., flat Earth vs. round Earth), thereby, in the name of neutrality, taking a positive, if perhaps condescending, ${ }^{6}$ position: that ridiculous or immoral positions are respectable (Nichols, 2017). If all positions are prima facie respectable (both cognitively and ethically), it is assumed that they are all sufficiently reasonable and decent (understood here as criteria for cognitive and ethical respectability). But if a predicate applies universally, it is meaningless, it says nothing about the subject. Therefore, in effect, when all opinions are treated as decent and reasonable, what happens is that decency and reasonableness are eliminated as criteria for evaluating discourse. Tolerance becomes something passive, an invitation to accept what is already instantiated, a way of preserving the status quo (Marcuse, 1969).

The mutual tolerance preached by relativists seems dangerously conducive to the persistence of cognitive bubbles. To say that all beliefs are equally valid is to say "don't touch my bubble, and I won't touch yours". In a media environment in which any belief can be reinforced by user selection, wrong and dangerous ideas can have real world effects if they are tolerated: that was the case of Brunswick North West Primary School in Melbourne, Australia, where it was explicitly decided that the beliefs of anti-vaccine conspiracy theorists would be tolerated and parents would not be forced to vaccinate their kids, with the predictable result that $25 \%$ of the student body contracted chicken pox, because of weakened herd immunity (Kluger, 2015). If CF is the product of cognitive bubbles, it must be fought by popping them.

$6 \quad$ It can be argued that such passive acceptance of points of view is a way of not engaging with them and that, rather, it is by agonistically facing the other that I may actually be transformed by the other. In the words of Miguel de Unamuno: "Only by trying to insert my spirit in the spirit of another do I receive the spirit of another in my own" ("Sólo cuando trato de meter mi espíritu en el espíritu de un prójimo mío es cuando recibo en el mío el espíritu de este mi prójimo" - our translation. Unamuno, 2007, p. 1013). 
This is not to say that treatment of CFs should not be respectful. At various times in history, the humiliation of fundamentalists has led to their radicalization: in the famous Scopes trial of 1925, in which John Scopes was put on trial for teaching the theory of evolution in the state of Tennessee, defense attorney Clarence Darrow called prosecution attorney William Jennings Bryan to the stand in order to show him up as ignorant of both biological and biblical science. This humiliation was seen as a triumph against fundamentalists, and commentators such as H.L Mencken piled on the humiliation; but the net result was that creationism, which had until then not been taken very seriously by fundamentalists, became a central concern for them and a rallying cry (Armstrong, 2009a, pp. 233-234). Similarly, the wearing of veils was not considered especially Islamic until it was criticized as backwards and sexist by secularist Egyptian writers at the beginning of the $20^{\text {th }}$ century (Armstrong, 2009a, p. 218). But confronting other people's ideas need not imply humiliating them: secularist efforts such as those of New Atheism (e.g., Stenger, 2009) must be evaluated not only in terms of content but also in terms of form.

\section{Concluding Remarks}

Is there such a thing as a fundamentalist mind? Formal similarities in the thinking of various groups and individuals that fit the bill seem to suggest there is. Furthermore, the study of these similarities promises to help us detect fundamentalist thinking, and predict developments in discussions with fundamentalists; it even suggests that certain epistemological positions may aid in creating an environment conducive to $\mathrm{CF}$. We have suggested above that epistemological relativism may produce a climate in which CF may flourish, because, as a habit of mind, $\mathrm{CF}$ behaves in a relativistic manner; it is an ecology of mind in which "anything goes". In as much as a culture espouses relativism, it also espouses habits of mind that, we believe, overlap with those of CF.

The year is 2020, and contentious issues in the public sphere include whether evolution is a fact, whether vaccination is a sound public policy, whether taking minimal precautions against a pandemic is a good idea, and whether the overwhelming scientific consensus over global warming should be heeded. In a broader sense, RFs exert a large and harmful influence on public policy (Rithven, 2005, p. 217). We have said nothing about the current holder of the most powerful elected position in the world, deeming it wiser to wait until the dust settles before 
taking a position on a development that promises to be momentous. The current state of the world may seem shocking to those who believe in the project of the Enlightenment, in which society as a whole is to become progressively more rational and reasonable. This challenge to Enlightenment can be undertaken in the spirit of the Enlightenment, which would surely aim "not to deride, bewail, or execrate human actions, but to understand them" (Spinoza, 2002, p. 681). The effort to understand fundamentalism must include input from psychology and the social sciences; but perhaps an epistemological perspective can also be helpful.

\section{References}

Aikin, S. \& Caisey, J. (2011). Straw Men, Weak Men and Hollow Men. Argumentation 25(1), 87-105.

Altemeyer, B. (2006). The Authoritarians. University of Manitoba. Author. Altemeyer, B. \& Hunsberger, B. (2004). A Revised Religious Fundamentalism Scale: The Short and Sweet of It. The International Journal for the Psychology of Religion, 14, 47-54.

Aragón, A. \& Ranulfo, O. (2013). La deconstrucción como movimiento de transformación. Ciencia, docencia y tecnología, 24(47), 79-93.

Armstrong, K. (2009a). Los orígenes del fundamentalismo en el judaísmo, el cristianismo y el islam. Tusquets.

(2009b, July 12). Metaphysical Mistake. The Guardian. URL: http:// www.theguardian.com/commentisfree/belief/2009/jul/12/religionchristianity-belief-science.

Aslan, R. (2010). Beyond Fundamentalism: Confronting Religious Extremism in the Age of Globalization. Random House.

Barbour, I. (2000). When Science Meets Religion. Harper Collins.

Bartlett, B. (2015). How Fox News Changed American Media and Political Dynamics, Social Science Research Network. DOI: http:// dx.doi.org/10.2139/ssrn.2604679.

Bateson, G. (1987). Steps to an Ecology of Mind. Jason Aronson.

Batson, C., Schoenrade, P. \& Ventis, W. (1993). Religion and Individual: A Social-Psychological Perspective. Oxford University Press.

Bogdan, R. (1985). Cognition and Epistemic Closure. American Philosophical Quarterly, 22(1), 55-63.

Boldeman, L. (2011). The Cult of the Market. ANU E Press.

Bonner, H. (1950). Sociological Aspects of Paranoia. American Journal of Sociology, 56(3), 255-262. 
Bruce, S. (2008). Fundamentalism. Polity.

Bonhoeffer, D. (1979). The Cost of Discipleship. Macmillan.

Bula, G. (2014). Apariencia y realidad en la economía neoclásica y el Hipias de Platón, Revista de Filosofía UIS, 13(1), 17-39.

Carter, D. (1999). From George Wallace to Newt Gingrich: Race in the Conservative Counterrevolution, 1963-1994. LSU Press.

Del Vicario, M., Bessi, A., Zollo, F., Petroni, F., Scala, A., Caldarelli, G., Stanley, H. \& Quatrociocchi, W. (2015). The Spreading of Misinformation Online. Proceedings of the National Academy of Sciences, 1-6. DOI: https://doi.org/10.1073/pnas.1517441113.

Douthat, R. (2010, April 16). The Conservative Mind, Circa 2010. The New York Times. URL: http://douthat.blogs.nytimes.com/2010/04/16/ the-conservative-mind-circa-2010/?_r=0.

Duck, R. \& Hunsberger, B. (1999). Religious Orientation and Prejudice: The Role of Religious Proscription, Right-Wing Authoritarianism, and Social Desirability. International Journal for the Psychology of Religion, 9, 157-179.

Dunlap, R. \& McCright, A. (2011). Organized Climate Change Denial. In J. S. Dryzek, R. B. Norgaard \& D. Schlossberg, D. (eds.), The Oxford Handbook of Climate Change and Society. (pp. 144-160). Oxford University Press.

Edwards, L. (2010). William F. Buckley Jr.: The Maker of a Movement. ISI Books.

Edwards, D. \& Webster, S. (2011). Confronted by Blogger, Santorum Fails to Differentiate Between Little Girl, Dish of Cells. Raw Story. URL: http://www.rawstory.com/2011/01/stark-interviews-santorumaudio/.

Fallaci, O. (2002). The Rage and the Pride. Rizzoli.

Fernandez, M. (2015, May 6). Conspiracy Theories Over Jade Helm Training Exercise Gain Some Traction in Texas. The New York Times. URL: http://www.nytimes.com/2015/05/07/us/conspiracy-theoriesover-jade-helm-get-some-traction-in-texas.html?_r=0.

Freedman, C. (2008). Chicago Fundamentalism: Ideology and Methodology in Economics. World Scientific Publishing.

Frost, D. (2007, September 7). I Have Impeached Myself. The Guardian. URL: http://www.theguardian.com/theguardian/2007/sep/07/ greatinterviews1.

Goodman, L. (2001). In Defense of Truth. Humanity Books 
Grieve, T. (2006). The Baby and the Petri Dish. Salon. URL: http://www. salon.com/2006/03/08/wilkow/.

Grosfoguel, R. (2011). Racismo epistémico, islamofobia epistémica y ciencias sociales coloniales. Tabula Rasa, 14, 341-355.

Guiora, A. (2014). Tolerating Intolerance: The Price of Protecting Extremism. Oxford University Press.

Harris, S. (2015). The End of Faith. W. W. Norton.

Harte, L. (2013). 'One and Indivisible': The Ideal of Undifferentiated Virtue as a Motivation for Violent Terrorism in Jihadist and Jacobin Circles. In J. Roshandel \& N. Lean (eds.), The Moral Psychology of Terrorism. (pp. 150-170). Cambridge Scholars Publishing.

Hathcoat, J. \& Barnes, L. (2010). Explaining the Relationship among Fundamentalism and Authoritarianism: An Epistemic Connection. The International Journal for the Psychology of Religion, 20, 73-84.

Hill, E., Terrell, H., Cohen, A., \& Nagoshi, C. (2010). The Role of Social Cognition in the Relgious Fundamentalism- Prejudice Relationship. Journal for the Scientific Study of Religion, 49(4), 724-739.

Jervis, R. (2016, January 8). Texas Allows Guns into State Mental Health Hospitals. USA Today. URL: http://www.usatoday.com/story/ news/2016/01/08/texas-open-carry-psychiatric-hospital/78522138/.

Klein, N. (2007). The Shock Doctrine. Picador.

Kluger, J. (2015, December 10). Why "Tolerating" Anti-Vaxxers Is a Losing Strategy. Time. URL: http://time.com/4144359/vaccinestolerance-anti-vaxxers-melbourne-australia/.

Kuhn, T. (2012). The Structure of Scientific Revolutions. University of Chicago Press.

Lehman, C. (2015). Apocalyptic Christianity and American Capitalism. Raritan, 34(4), 36-54.

Levy, P. (1999). Collective Intelligence. Basic Books.

Maalouf, A. (2012). Identidades asesinas. Alianza.

Marcuse, H. (1969). Repressive Tolerance. In P. Wolf, B. Moore H. \& Marcuse, A Critique of Pure Tolerance. (pp. 81-123). Beacon Press.

Mercer, C. (2013). The Male Warrior God and the Threatened Egotism of his Mighty Men. In J. Roshandel \& N. Lean (eds.), The Moral Psychology of Terrorism. (pp. 135-149). Cambridge Scholars Publishing.

Minsky, M. (2010). La máquina de las emociones. Random House Mondadori.

Nash, G. (2009). Reappraising the Right: The Past and Future of American Conservatism. ISI Books. 
Nichols, A. (2017, August 28). The Meaning of Tolerance. Current Affairs. URL: $\quad$ https://www.currentaffairs.org/2017/08/the-meaning-oftolerance.

O'Clock, J. (2015). Human Sexuality-Anything Goes? Living Word International Christian Church. URL: http://www. livingwordinternationalchristianchurch.org/images/ministries/prolife/pdf/Human_Sexuality_Anything_Goes_revAugust2015.pdf.

Payne, S. (2003). A History of Fascism: 1914-45. Taylor \& Francis Group.

Ramsay, C., Kull, S., Lewis, E. \& Subias, S. (2010). Misinformation and the 2010 Election. WorldPublicOpinion.org.

Resnick, M. (2000). Turtles, Termites and Traffic Jams: Explorations in Massively Parallel Microworlds. MIT Press.

Robin, C. (2011). The Reactionary Mind. Oxford University Press.

Ruthven, M. (2005). Fundamentalism: The Search of Meaning. Oxford University Press.

Saletan, W. (2010, May 3). Bubble Think: How to Escape a Partisan Echo Chamber. Slate.com. URL: http://www.slate.com/articles/news_and_ politics/frame_game/2010/05/bubble_think.html.

Sanchez, J. (2010a, April 7). Epistemic Closure, Technology and the End of Distance. Juliansanchez.com. URL: http://www.juliansanchez. com/2010/04/07/epistemic-closure-technology-and-the-end-ofdistance/. (2010b, April 22). A Coda on Closure. Juliansanchez.com. URL: http:// www.juliansanchez.com/2010/04/22/a-coda-on-closure/.

Sarouglou, V. (2002). Beyond Dogmatism: The Need for Closure as Related to Religion. Mental Health, Religion \& Culture, 5(2), 183-194.

Schimmel, S. (2008). The Tenacity of Unreasonable Beliefs. Oxford University Press.

Schneider, S. (2002). Fundamentalism and Paranoia in Groups and Society. Group Therapy in Israel, 26(1), 17-27.

Schwartz, S. \& Huismans, S. (1995). Value Priorities and Religiosity in Four Western Religions. Social Psychology Quarterly, 58, 88-107. Simmel, G. (1964). Conflict. The Web of Group-Affiliations. The Free Press Sorel, G. (1925). Reflections on Violence. George Allen \& Unwin LTD. Spinoza, B. (2002). Complete Works. Hackett.

Stenger, V. (2009). The New Atheism: Taking a Stand for Science and Reason. Prometheus.

Sunstein, C. (2003). República.com: Internet, democracia y libertad. Paidós. 
Taverne D. (2005). The March of Unreason: Science, Democracy and the New Fundamentalism. Oxford University Press.

Thompson, H. (2015, August 5). Teen Schools Professor on "No Irish Need Apply" Signs. Smithsonian Magazine. URL: https://www. smithsonianmag.com/smart-news/teen-schools-professor-no-irishneed-apply-signs-180956162/.

Unamuno, M. (2007). Obras completas VIII. Ensayos. Fundación José Antonio de Castro.

Warburton, N. (2000). Thinking from A to Z. Routledge.

Watson, P., Morris, R., Hood, R., Miller, L. \& Waddell, M. (1999). Religion and the Experiential System: Relationships of Constructive Thinking with Religious Orientation. International Journal for the Psychology of Religion, 9, 195-207.

Williams, D. (2010). God's Own Party: The Making of the Christian Right. Oxford.

Woodmorappe, J. (2013, October 15). How Could Noah Fit the Animals on the Ark and Care for Them? Answers in Genesis. URL: https:// answersingenesis.org/noahs-ark/how-could-noah-fit-the-animalson-the-ark-and-care-for-them/.

Wright, L. (1993). Saints and Sinners. Knopf.

Zimet, A. (2015, June 2). More Guns for Everyone! Idaho School Arms Teachers and What could Possibly go Wrong? Common Dreams. URL: http://www.commondreams.org/further/2015/06/02/more-gunseveryone-idaho-school-arms-teachers-and-what-could-possibly-gowrong.

Zwierlein, C. \& de Graaf, B. (2013). Security and Conspiracy in Modern History. Historical Social Research, 38(1(143)), 7-45. 
